\title{
Porównanie metod cięcia termicznego stali
}

\section{Comparison of thermic cutting steel methods}

\section{Streszczenie}

Przedstawiono wyniki badań materiałów po procesie cięcia termicznego tlenowego, laserowego i plazmowego. Przeprowadzono ocenę powierzchni i krawędzi cięcia, badania metalograficzne oraz pomiary twardości. Porównano uzyskane wyniki badań cięcia termicznego.

Słowa kluczowe: cięcie termiczne, cięcie tlenowe, cięcie laserowe, cięcie plazmowe, własności powierzchni i strefy cięcia, twardość, metalografia

\section{Abstract}

Presents the research results of material after the process of thermic oxygen, laser and plasma cutting. Conduct an assessment of the surface and cutting edge, metallographic tests and hardness measurements. Compared and evaluated the research results of thermic cutting.

Keywords: thermal cutting, oxy-cutting, laser cutting, plasma cutting, surface properties and cutting zone, hardness, metallography

\section{Wstęp}

Próby cięcia termicznego tlenowego, laserowego oraz plazmowego wykonano na blachach o grubości $18 \mathrm{~mm}$ ze stali S355J2 w warunkach zautomatyzowanych. Po wykonaniu prób cięcia termicznego z próbek o wymiarach $100 \times 200 \mathrm{~mm}$ pobrano do badań wycinki o wymiarach $24 \times 100 \mathrm{~mm}$. Na powierzchniach i krawędziach próbek po cięciu przeprowadzono szczegółowe oględziny $i$ ich ocenę [5]. Na pobranych wycinkach z próbek wykonano zgłady metalograficzne obejmujące przekroje poprzeczne do linii cięcia, na których po wytrawieniu ujawniono strefę przyległą do powierzchni cięcia. Do wytrawienia powierzchni zgładów metalograficznych makroskopowych i mikroskopowych użyto odczynnika Nital o stężeniu 8 i 5\%. Na przygotowanych próbkach przeprowadzono następujące badania:

- badania makrostrukturalne obejmujące oględziny powierzchni ciętych nieuzbrojonym okiem, a następnie przy powiększeniach x10 i x40 z użyciem mikroskopu cyfrowego Olympus [6],

- badania mikrostrukturalne przy powiększeniach x150 oraz x500. Zdjęcia struktur przy powiększeniu x150 i x500 zostały zrealizowane na mikroskopie cyfrowym Olympus,

- badania twardości na powierzchniach po cięciu oraz na przekroju poprzecznym w strefie przyległej do powierzchni cięcia wykonano metodą Vickersa z użyciem twardościomierza MIC 10 i HPO 250 [7].

\section{Ocena jakości powierzchni cięcia}

$\mathrm{Na}$ przedstawionych poniżej rysunkach pokazano w widoku fragmenty powierzchni próbek ze stali S355J2 po cięciu tlenowym - rysunek 1, laserowym - rysunek 2 i plazmowym - rysunek 3. Próbę cięcia tlenowego wykonano z prędkością cięcia $v=465 \mathrm{~mm} / \mathrm{min}$ i z ciśnieniem tlenu tnącego $p=6$ bar. Próbę cięcia laserowego przeprowadzono $\mathrm{z}$ prędkością cięcia $\mathrm{v}=860 \mathrm{~mm} / \mathrm{min}$ i mocą wiązki $3200 \mathrm{~W}$ $\mathrm{z}$ gazem $\mathrm{O}_{2}$ o ciśnieniu $\mathrm{p}=0,62$ bara. $\mathrm{Z}$ kolei próbę cięcia plazmowego wykonano z prędkością cięcia $1485 \mathrm{~mm} / \mathrm{min}$ z zastosowaniem powietrza jako gazu plazmowego i natężeniem prądu cięcia 200A.

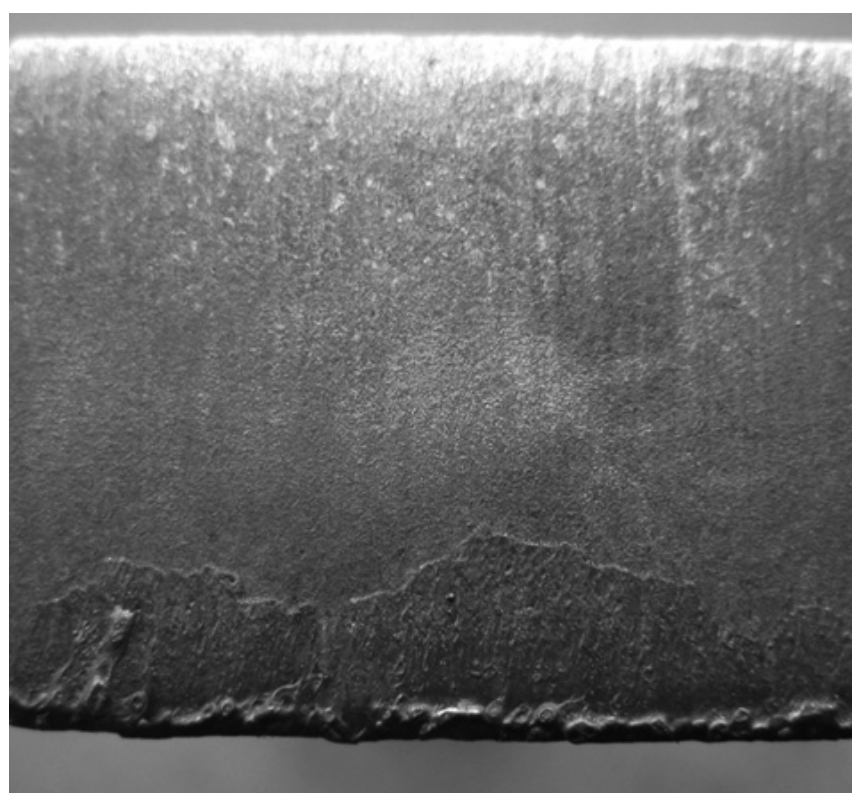

Rys. 1. Powierzchnia po cięciu termicznym stali metodą tlenową Fig. 1. Surface of steel after the thermal cutting by oxygen method 


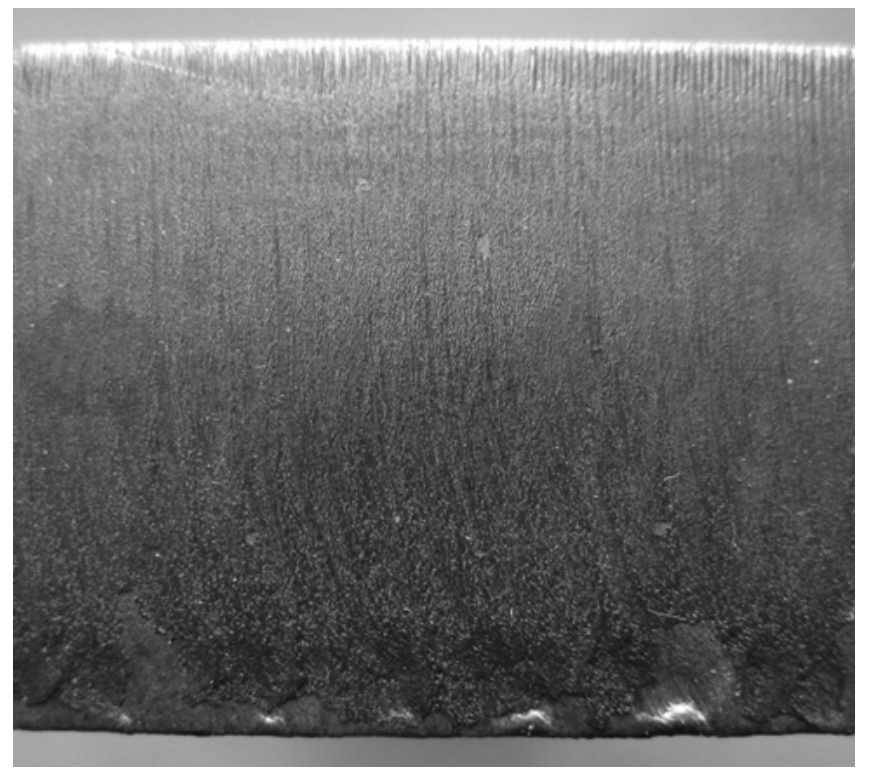

Rys. 2. Powierzchnia po cięciu termicznym stali metodą laserową Fig. 2. Surface of steel after the thermal cutting by laser method

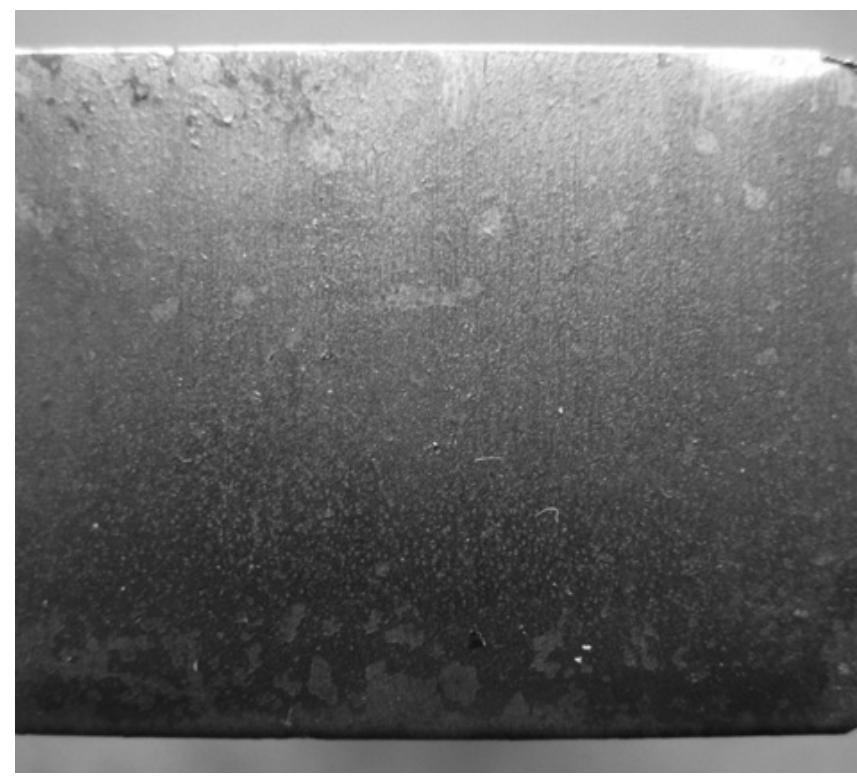

Rys. 3. Powierzchnia po cięciu termicznym stali metodą plazmową Fig. 3. Surface of steel after the thermal cutting by plasma method

Ocenie poddano stan powierzchni po cięciu biorąc pod uwagę jej gładkość, występowanie wyżłobień, nawisów przy dolnej krawędzi cięcia oraz nadtopień przy górnej krawędzi cięcia. Biorąc pod uwagę powyższe kryteria najlepszą jakość stwierdzono na powierzchni po cięciu plazmowym (rys.3). Powierzchnia po cięciu plazmowym jest gładka, brak na niej często występujących wyżłobień, które powodowane są nieodpowiednim doborem parametrów cięcia jak i ograniczeniami sprzętowymi. Na powierzchni po cięciu laserowym (rys.2) są zauważalne wyżłobienia przy górnej krawędzi cięcia, które w dolnej części blachy uległy zakrzywieniu oraz nawisy przy dolnej krawędzi cięcia [3]. Takie zjawisko ma miejsce, jak już wspomniano, w przypadku nieodpowiedniego dopasowania parametrów cięcia. Przy grubszych materiałach, tak jak badany o grubości $18 \mathrm{~mm}$, jest ono spowodowane ograniczeniami mocy wiązki wytwarzanej przez generator laserowy. Najgorszą powierzchnię cięcia można jednak zaobserwować po procesie cięcia tlenowego (rys.1). Na jej powierzchni widoczne są wyraźne wyżłobienia, które są najgłębsze przy górnej krawędzi cięcia, natomiast przy dolnej krawędzi występuje trudna do usunięcia zendra oraz żużlowy nawis [1]. Takie czynniki znacznie utrudniają obróbkę elementów po cięciu, co jest wyraźnym utrudnieniem w dalszych procesach produkcyjnych [2].

Po wykonaniu oceny wizualnej na powierzchniach próbek po cięciu wykonano badania twardości metodą Vickersa HV5. Pomiary wykonano na wszystkich powierzchniach wzdłuż grubości próbki, a wyniki zamieszczono w tablicy I.

Tablica I. Wyniki pomiarów twardości HV5 na powierzchniach po cięciu

Table I. The results of hardness measurements on the surface HV5 after cutting

\begin{tabular}{|c|c|c|c|}
\hline \multirow{2}{*}{ HV } & \multicolumn{3}{|c|}{ Proces cięcia termicznego } \\
\cline { 2 - 4 } & PLAZMOWE & LASEROWE & TLENOWE \\
\hline 1 & $414 \mathrm{HV}$ & $323 \mathrm{HV}$ & $559 \mathrm{HV}$ \\
\hline 2 & $397 \mathrm{HV}$ & $316 \mathrm{HV}$ & $601 \mathrm{HV}$ \\
\hline 3 & $412 \mathrm{HV}$ & $308 \mathrm{HV}$ & $585 \mathrm{HV}$ \\
\hline 4 & $391 \mathrm{HV}$ & $303 \mathrm{HV}$ & $564 \mathrm{HV}$ \\
\hline
\end{tabular}

Z wyników pomiarów twardości wynika, że największe utwardzenie powierzchni po cięciu termicznym występuje przy cięciu tlenowym dla którego twardości osiągają wartości na poziomie ok. $600 \mathrm{HV}$. Najmniejsze z kolei utwardzenie, na poziomie dwukrotnie niższym ok. $300 \mathrm{HV}$, stwierdzono na powierzchni cięcia metodą laserową. Na powierzchni po cięciu plazmowym zmierzono twardość na poziomie ok.400HV.

Następne badania przeprowadzono na przekrojach poprzecznych próbek po cięciu termicznym tlenowym, laserowym i plazmowym. W tym celu wykonano na próbkach zgłady metalograficzne makroskopowe w celu ujawnienia strefy oddziaływania termicznego źródła ciepła w procesie cięcia. Zdjęcia zgładów makroskopowych zostały wykonane za pomocą mikroskopu cyfrowego Olympus przy powiększeniach odpowiednio x10 - rysunki 4, 5 i 6 oraz x40 - rysunki 7,8 i 9.



Rys. 4. Przekroju próbki po cięciu tlenowym. Pow. x10

Fig. 4. The sectional view of the sample after cutting oxygen. Magnification x 10 


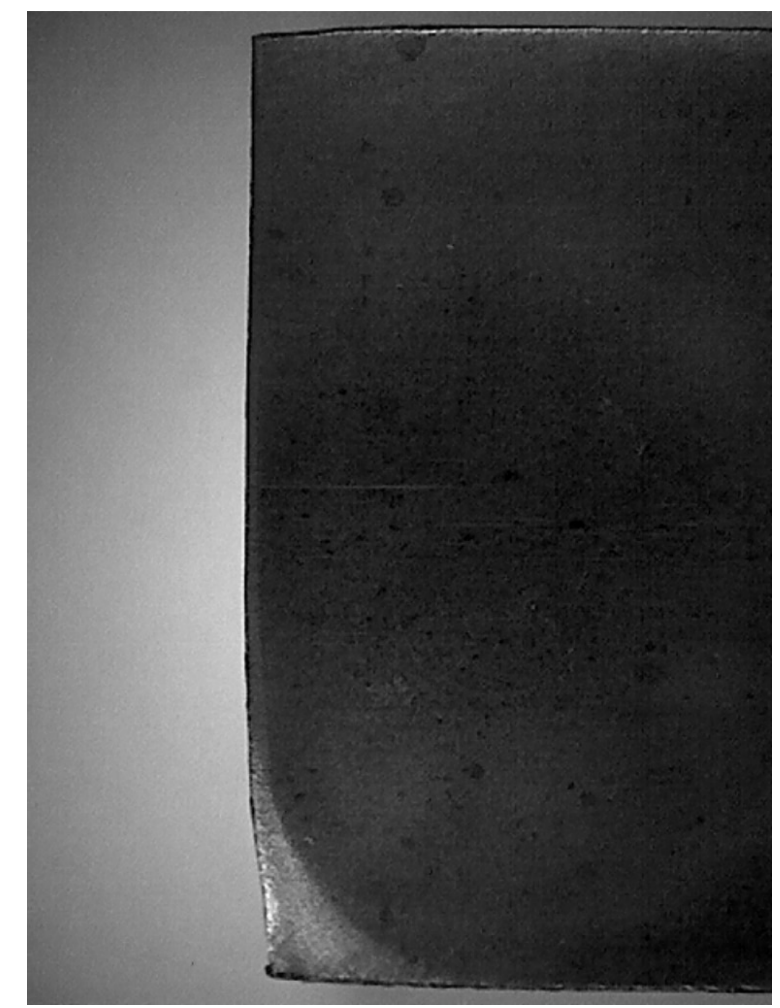

Rys. 5. Przekroju próbki po cięciu laserowym. Pow. x10 Fig. 5. The sectional view of the sample after cutting oxygen. Magnification $\times 10$

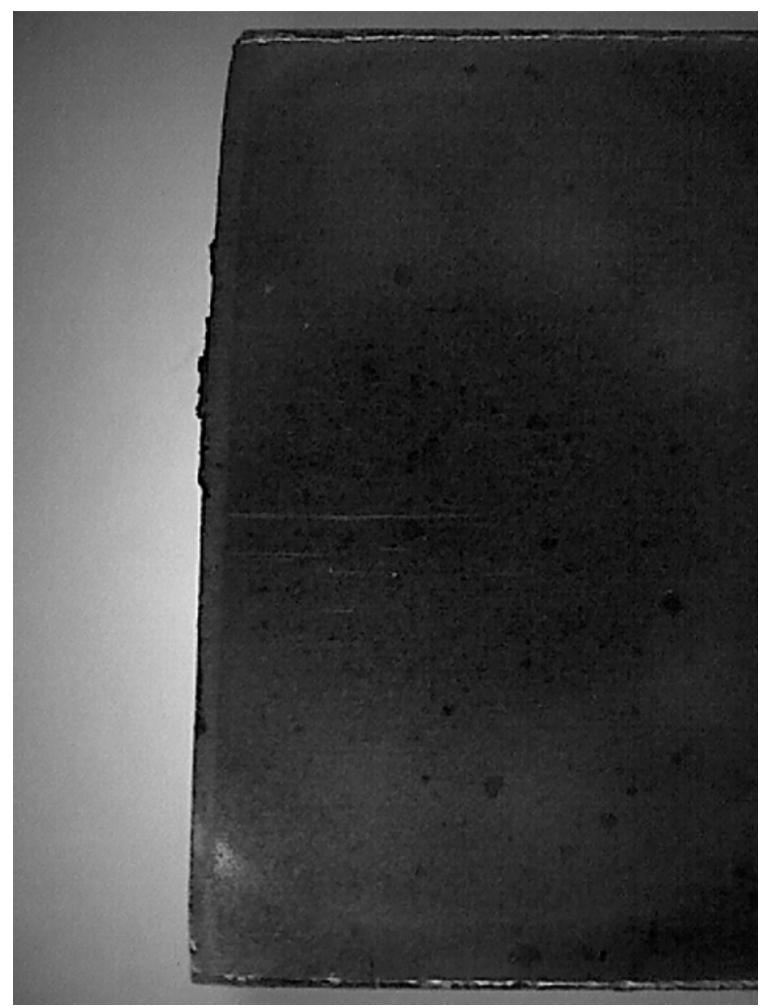

Rys. 6. Przekroju próbki po cięciu plazmowym. Pow. x10

Fig. 6. The section view sample after plasma cutting. Magnification x10

Na rysunku 4 przedstawiającym zgład wykonany na próbce ze stali S355J2 po cięciu tlenowym można zaobserwować strefę wpływu ciepła o szerokości od $1 \mathrm{~mm}$ w górnej strefie do $3 \mathrm{~mm}$ w dolnej. Widoczne jest również zaokrąglenie zarówno górnej jak i dolnej krawędzi cięcia. Zauważalne jest także zukosowanie próbki zawężające szczelinę cięcia. Zaokrąglenie krawędzi poprzez ich nadtopienie spowodowane jest bardzo dużym wpływem ciepła na cięty materiał. Powodem zukosowania natomiast może być nierówny płomień palnika, zbyt niskie ciśnienie gazu tnącego lub odchylenie palnika od pionu.

W przypadku cięcia laserowego (rys. 5) zarówno górna jak i dolna krawędź cięcia nie posiadają zaokrągleń ponieważ ciepło procesu cięcia nie ingeruje w tak dużym stopniu na materiał jak w procesie cięcia tlenowego. Zauważalne jest tutaj niewielkie wybrzuszenie powierzchni ciętej spowodowane prawdopodobnie osłabieniem wiązki laserowej, która z kolei przy dolnej krawędzi cięcia ulega w pewnym stopniu rozproszeniu powodując wyżłobienie właśnie w okolicy dolnej krawędzi cięcia. Szerokość strefy wpływu ciepła wynosi ok. 0,2 mm w górnej strefie do ok. 0,4 $\mathrm{mm}$ w dolnej.

Na górnej krawędzi w procesie ciecia plazmowego (rys. 6) występuje niewielkie zaokrąglenie, ponieważ zawirowany strumień plazmowy o bardzo wysokiej temperaturze i z duża prędkością dzieli materiał bez najmniejszych przeszkód nie powodując tutaj nadtopienia krawędzi. Jednak im bardziej w głąb materiału tym większe występuje zukosowanie ściany cięcia, zwężając tym samym szczelinę cięcia coraz słabszym i bardziej zawężonym strumieniem. Na dolnej krawędzi cięcia brak zaokrąglenia, a szerokość strefy wpływu ciepła wynosi ok. 0,5 do 0,8 mm w całej strefie.

Fotografie zgładów makroskopowych przedstawione poniżej na rysunkach 7, 8 i 9 zostały wykonane za pomocą mikroskopu cyfrowego Olympus przy powiększeniach x40 w dwóch częściach obejmujących odpowiednio przekrój od góry a następnie od dołu. Przy takim powiększeniu możliwe było przeprowadzenie znacznie bardziej szczegółowych oględzin w wybranych obszarach.
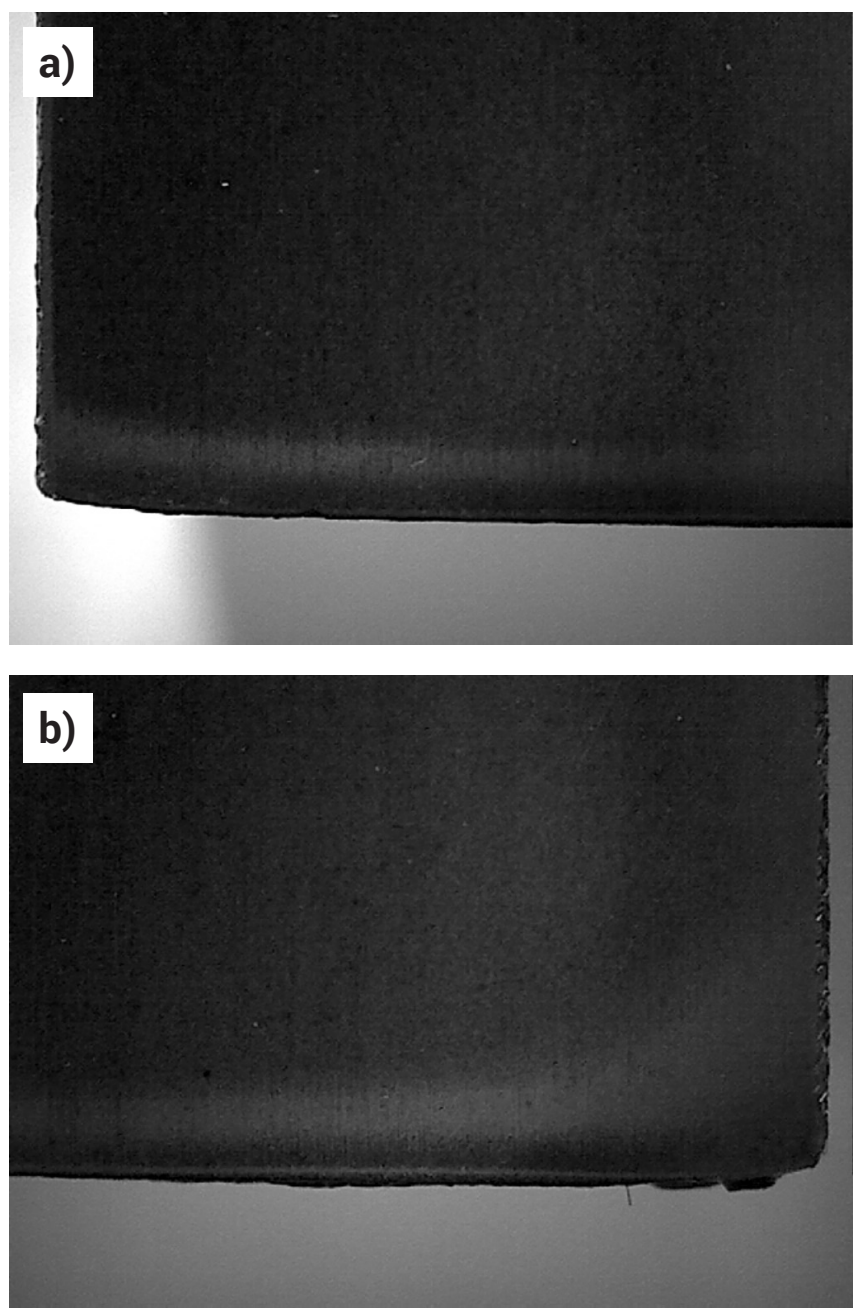

Rys. 7. Przekroju próbki po cięciu tlenowym: a) od górnej krawędzi, b) od dolnej krawędzi. Pow. x40

Fig. 7. The sectional view of the sample after cutting oxygen: a) from the upper edge, b) from the bottom edge. Magnification x40 




\section{b)}

Rys. 8. Przekroju próbki po cięciu laserowym: a) od górnej krawędzi, b) od dolnej krawędzi. Pow. $x 40$

Fig. 8. The sectional view of the sample after laser cutting: a) from the upper edge, b) from the bottom edge. Magnification $x 40$
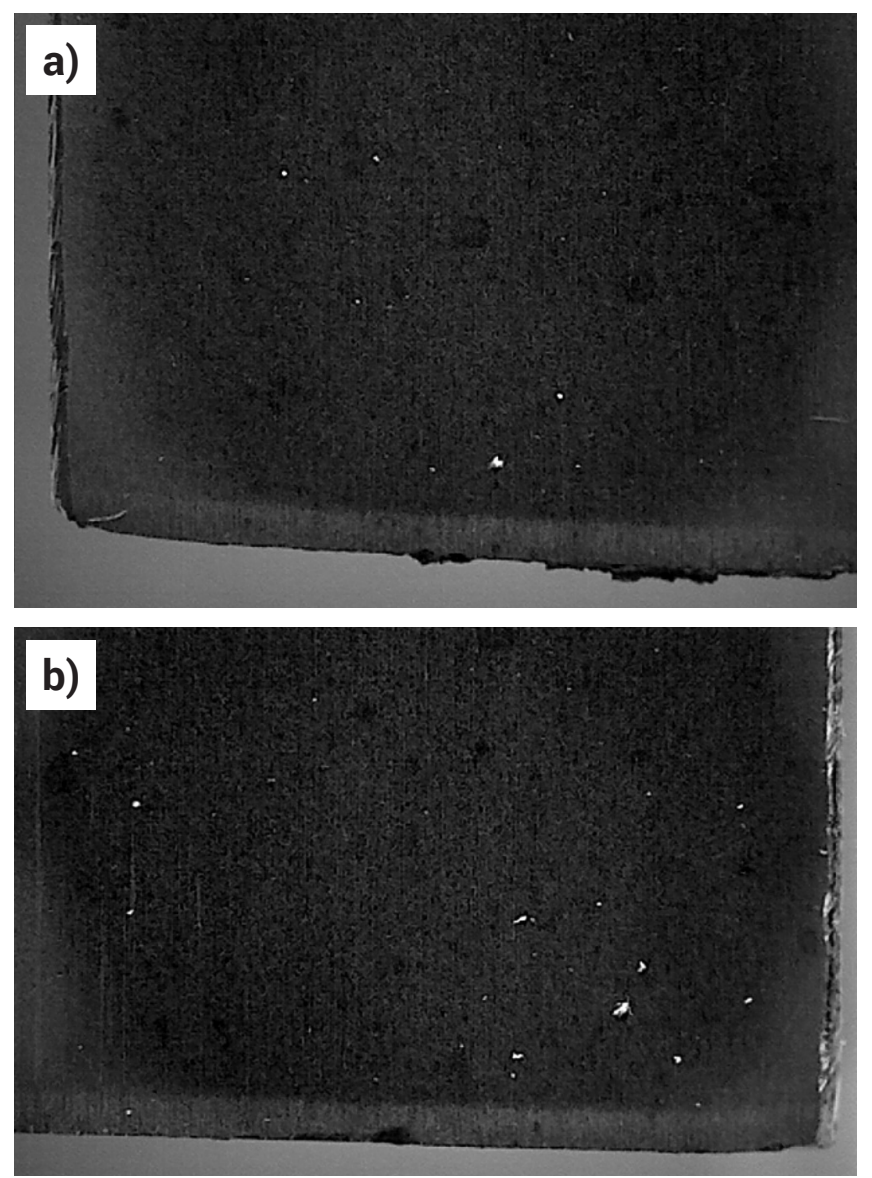

Rys. 9. Przekroju próbki po cięciu plazmowym: a) od górnej krawędzi, b) od dolnej krawędzi. Pow. x40

Fig. 9. The sectional view of the sample after plasma cutting: a) from the upper edge, b) from the bottom edge. Magnification $\times 40$
Przedstawione poniżej rysunki 10, 11 i 12 ilustrują stan powierzchni na fragmentach mikrozgładów próbek stali S355J2 przy powiększeniu x150. Takie powiększenie daje możliwość obserwacji defektów powierzchni zgładu i krawędzi ściany cięcia oraz innych nieciągłości materiałowych.

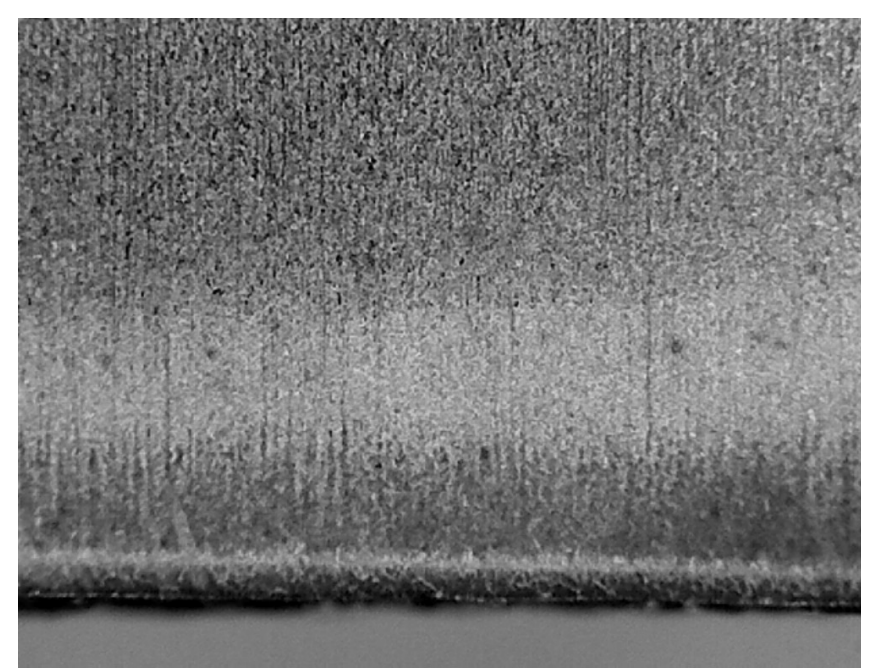

Rys. 10. Fragmentu przekroju próbki po cięciu tlenowym. Pow. x150 Fig. 10. The view part section of the sample after cutting oxygen. Magnification x 150

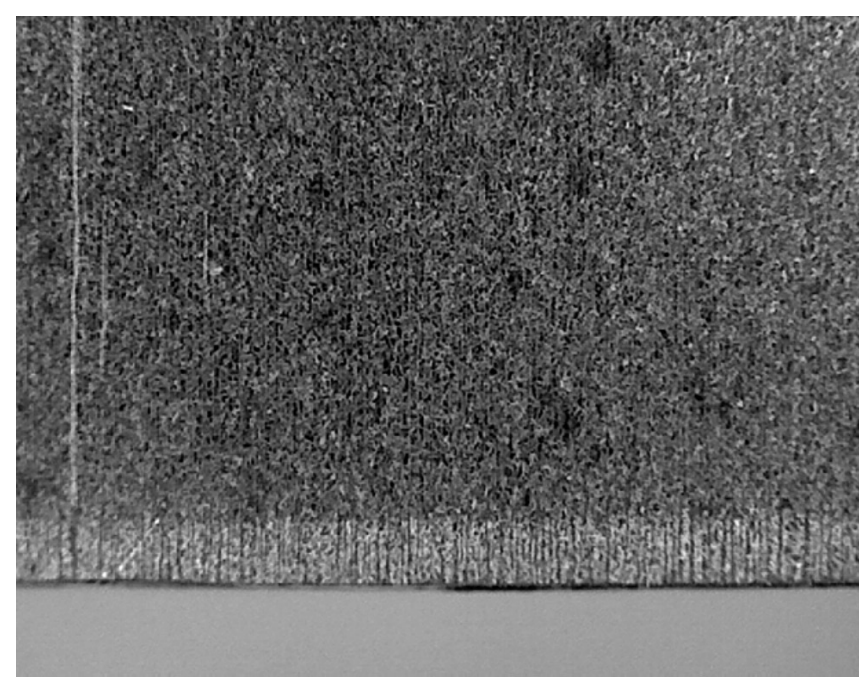

Rys. 11. Fragment przekroju próbki po cięciu laserowym. Pow. x150 Fig. 11. The view part section of the sample after laser cutting

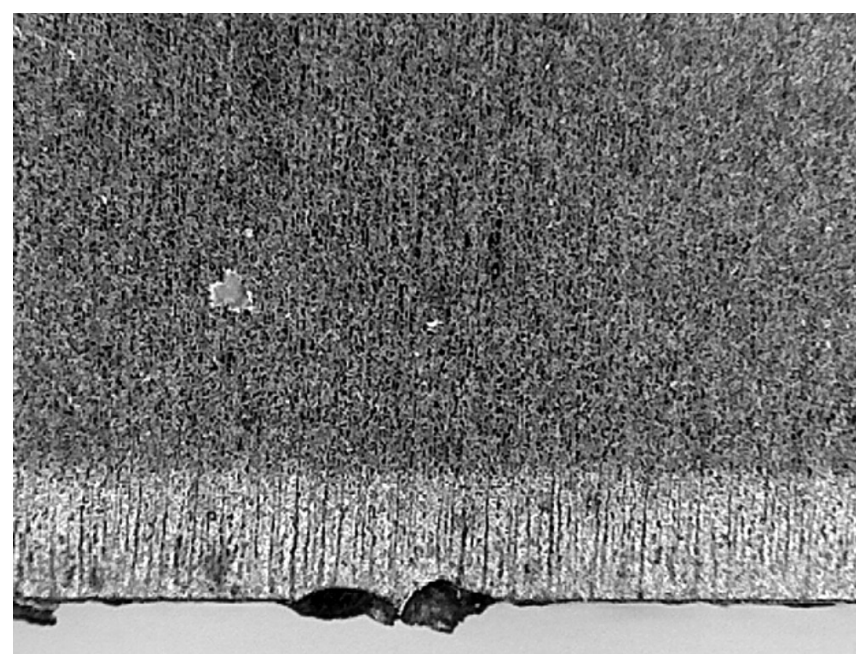

Rys. 13. Fragment przekroju próbki po cięciu plazmowym. Pow. x150 Fig. 13. The view part section of the specimen after plasma cutting. Magnification x150

\section{PRZEGLAD SPAWALNICTWA Vol. 87 7/2015}


Na przekroju próbki ze stali po cięciu tlenowym (rys. 10) można zauważyć strefę zahartowania materiału spowodowaną bardzo dużą ingerencją ciepła na przecinany materiał.

Z kolei na rysunku 11 obrazującym fragment próbki po cięciu laserowym można zaobserwować rysy powstałe w procesie polerowania, jednak na większą uwagę zasługuje bardzo dobry stan krawędzi ściany cięcia.

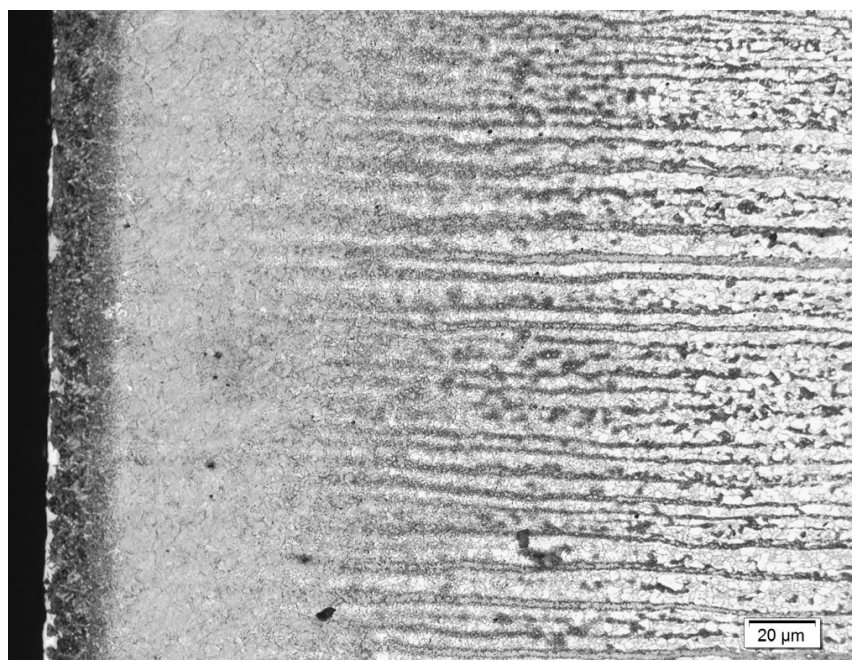

Rys. 13. Fragment przekroju próbki po cięciu tlenowym. Pow. x500 Fig. 13. The view part section of the sample after cutting oxygen. Magnification $\times 500$
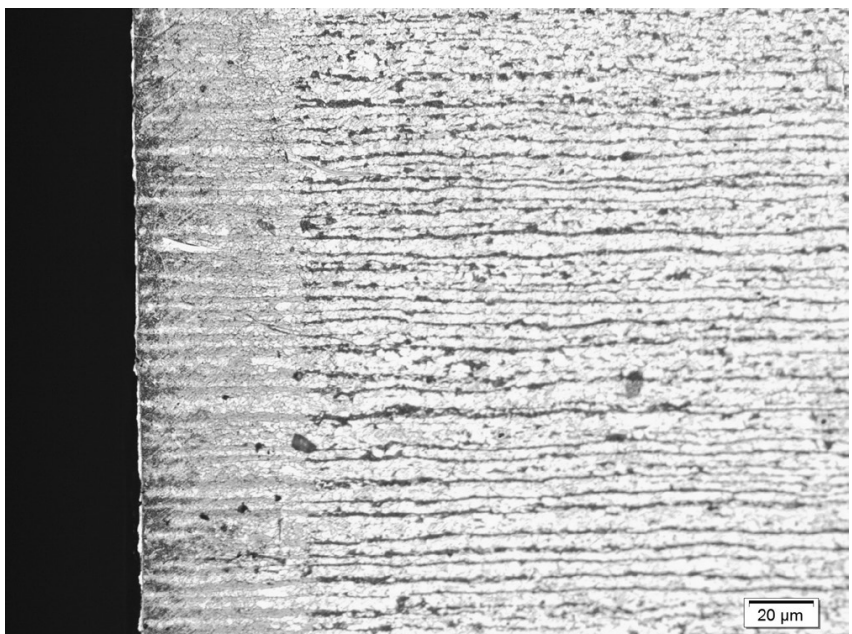

Rys. 14. Fragment przekroju próbki po cięciu laserowym. Pow. x500 Fig. 14. The view part section of the sample after laser cutting. Magnification $\times 500$

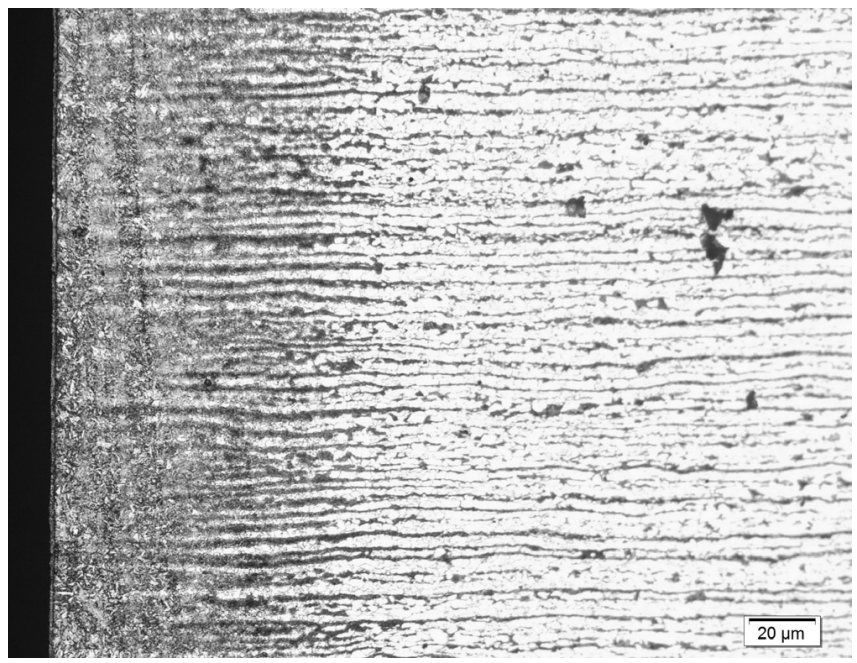

Rys. 15. Fragment przekroju próbki po cięciu plazmowym. Pow. x500 Fig. 15. The view part section of the specimen after plasma cutting. Magnification $\times 500$
Na ostatnim rysunku obrazującym fragment powierzchni zgładu oraz ściany cięcia przy powiększeniu x 150 występuje wtrącenie w materiale w postaci zanieczyszczenia, a także wyrwanie fragmentu materiału ze ściany cięcia powstałe w procesie obróbki próbki.

Rysunki 13, 14 i 15 obrazują mikrostrukturę stali S355J2 po cięciu termicznym obserwowaną w 500-krotnym powiększeniu.
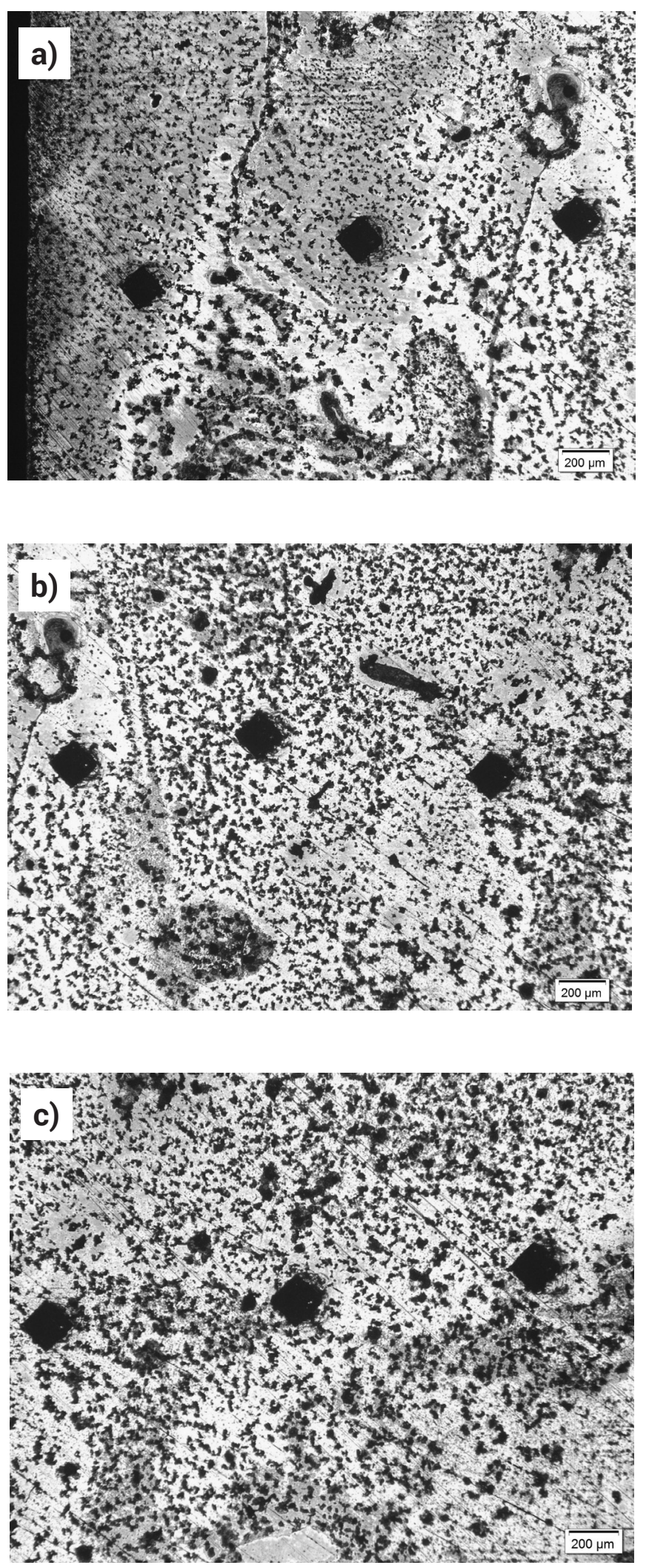

Rys. 16. Rozkład pomiaru twardości w strefie wpływu ciepła na próbce po cięciu tlenowym. Od lewej kolejno: odciski 1-3, 3-5 i 5-7 Fig. 16. Distribution of measuring the hardness in the heat affected zone on the sample after oxygen cutting. From the left order. fingerprints $1-3,3-5$ and $5-7$ 
Dzięki zamieszczonej na rysunku podziałce można z pewnym przybliżeniem określić szerokość strefy wpływu ciepła. Z rysunku 13 wynika, że SWC w badanym fragmencie stali po cięciu tlenowym ma szerokość od 2,0 do 2,5 mm, natomiast szerokość strefy zdegradowanej zbyt dużym wpływem ciepła na materiał, czyli strefy gdzie materiał uległ zahartowaniu wynosi około $0,2 \mathrm{~mm}$.

Obserwując kolejny rysunek 14 przedstawiający próbkę stali po cięciu laserowym, można zauważyć ogromną różnicę pomiędzy tlenową a laserową metodą cięcia termicznego, ponieważ szerokość SWC dla cięcia laserowego wynosi poniżej 0,5mm. Zatem szerokość strefy wpływu ciepła przy cięciu stali S355 jest od czterech do pięciu razy mniejsza.

Sytuacja pośrednia, jeżeli chodzi o pomiar szerokości stery wpływu ciepła, występuje przy cięciu stali metodą plazmową [4]. Szerokość SWC wynosi tutaj poniżej jednego milimetra.

Po przeprowadzeniu badań makroskopowych oraz mikroskopowych struktury stali po cieciu termicznym wykonano badania twardości na przygotowanych zgładach próbek po cięciu stali. Badanie twardości zostało przeprowadzone metodą Vickersa HV5 za pomocą twardościomierza HPO-250. Pomiary wykonano z podziałką 0,5 do 0,7 mm na przekroju poprzecznym w linii począwszy od krawędzi w głąb materiału. Przykładowy rozkład pomiarów twardości przedstawiono na rysunku 16 ilustrującym wykonane odciski na próbce po cięciu tlenowym. Obraz zarejestrowano na mikroskopie z powiększeniem x50.

Wyniki pomiarów na powierzchni cięcia i na przekroju poprzecznym przedstawiono w tablicy II.

Przedstawione w tablicy II wyniki pomiarów twardości metodą Vickersa dla poszczególnych metod cięcia, a więc tlenowego, laserowego oraz plazmowego obrazują zmiany własności materiału w wyniku oddziaływania źródła ciepła w procesie cięcia termicznego. Należy zauważyć,żenajwiększe utwardzenie materiału zarówno na powierzchni cięcia jak i przy krawędzi ściany cięcia wystąpiło w przypadku metody cięcia tlenowego. W przypadku metody plazmowej stopień utwardzenia materiału jest nieznaczny i jedynie w strefie przypowierzchniowej. W metodzie laserowej nie stwierdzono występowania strefy utwardzonej. Rozkład twardości na przekrojach w kierunku materiału rodzimego wykazuje stopniowe obniżanie aż do poziomu twardości materiału i odpowiada w przybliżeniu szerokościom stref zmian w strukturze materiału.

Tablica II. Wyniki pomiarów twardości HV5 na powierzchni i przekrojach próbek po cięciu

Table II. The results of hardness measurements HV5 on the surface and cross sections of samples after cutting

\begin{tabular}{|c|c|c|c|c|c|c|c|c|}
\hline \multirow{2}{*}{$\begin{array}{c}\text { Metoda } \\
\text { cięcia }\end{array}$} & $\begin{array}{c}\text { Pomiar } \\
\text { średni na } \\
\text { pow. cięcia }\end{array}$ & \multicolumn{8}{|c|}{ Nr punktu pomiarowego na przekroju poprzecznym } \\
\cline { 3 - 10 } & 577 & 306 & 2 & 3 & 4 & 5 & 6 & 7 \\
\hline Tlenowe & 312 & 229 & 212 & 196 & 167 & - & - & 162 \\
\hline Laserowe & 404 & 249 & 223 & 221 & 192 & 176 & - & - \\
\hline Plazmowe & 404 & & 228 & 214 & - \\
\hline
\end{tabular}

\section{Podsumowanie}

Przeprowadzenie badań porównawczych dla trzech metod cięcia termicznego stali, czyli metody tlenowej, laserowej oraz plazmowej miało na celu porównanie podstawowych własności materiału w poszczególnych metodach cięcia.

Należy zauważyć, że w przypadku cięcia laserowego ograniczeniem była grubość ciętej blachy. Analizując powierzchnię krawędzi cięcia termicznego można zaobserwować liczne wyżłobienia oraz zakrzywienia wyżłobień, które powstały w wyniku nieprawidłowego doboru parametrów cięcia bądź też ograniczeń technicznych urządzenia. Nie wystąpiło tutaj zaokrąglenie górnej krawędzi cięcia, natomiast w okolicach dolnej krawędzi wystąpiło nadtopienie i wyrzucenie części materiału, które było wynikiem rozproszenia się osłabionej wiązki. Podczas cięcia grubych blach jakość cięcia nie była zadowalająca, a samo cięcie realizowane było przy stosunkowo niskich prędkościach.

Cięcie tlenowe blach stalowych o dużych przekrojach przebiegało przy niewielkich prędkościach, jednak estetyka wykonania cięcia była lepsza niż w przypadku cięcia laserowego. Na ścianach cięcia blach wystąpiła trudna do usunięcia zendra oraz nawisy żużlowe przy dolnych krawędziach cięcia, co niewątpliwie jest utrudnieniem w procesie produkcyjnym.

Biorąc pod uwagę zarówno prędkość cięcia, jak i jakość powierzchni cięcia najlepszą metodą cięcia termicznego blach stalowych o grubości $18 \mathrm{~mm}$ okazało się cięcie plazmowe. Jakość krawędzi cięcia była zadowalająca, a szerokość strefy wpływu ciepła znajdowała się w średniej wartości dla trzech badanych metod. Należy jednak pamiętać, że jest to najbardziej szkodliwa metoda cięcia termicznego dla zdrowia człowieka, gdzie możliwe są między innymi choroby wzroku, słuchu, jak i układu oddechowego.

\section{Literatura}

[1] Praca zbiorowa: Poradnik inżyniera. Spawalnictwo. Tom 2, Wydawnictwa Naukowo-Techniczne, Warszawa 2005.

[2] Kaczmarek R., Krawczyk R.: Projektowanie i wytwarzanie konstrukcji spawanych w aspekcie możliwości przeprowadzania badań ultradźwiękowych złączy. Przegląd Spawalnictwa 2014, nr 7, str. 22-29.

[3] Słania J., Milewski P.: Porównanie cięcia laserowego z cięciem strumieniem wodno-ściernym. Przegląd Spawalnictwa 2014, nr 7, str. 30-40.

[4] Słania J., Wilk P.: Analiza i porównanie trwałości elektrod stosowanych podczas zmechanizowanego cięcia plazmowego. Przegląd Spawalnictwa $2014, \mathrm{nr}$ 7, str. 40-53.
[5] PN-EN ISO 17637: Badania nieniszczące złączy spawanych - Badania wizualne złączy spawanych.

[6] PN-EN ISO 17639: Spawalnictwo - Badania niszczące metalowych złączy spawanych - Badania makroskopowe i mikroskopowe złączy spawanych.

[7] PN-EN ISO 6507-1: Metale - Pomiar twardości sposobem Vickersa - Część 1: Metoda badań. 